\title{
Linkage between solid phase apportionment and bioaccessible arsenic, chromium and lead in soil from Glasgow, Scotland, UK.
}

|Joanna Wragg ${ }^{a^{*}}$, Andrew Broadway ${ }^{\mathrm{c}}$, Mark R. Cave ${ }^{\mathrm{a}}$, Fiona M. Fordyce ${ }^{\mathrm{b}}$, Barbara Palumbo-Roe ${ }^{\mathrm{a}}$

Darren J. Beriro ${ }^{a}$, John G. Farmer ${ }^{\mathrm{c}}$, Margaret C. Graham ${ }^{\mathrm{c}}$, Bryne T. Ngwenya ${ }^{\mathrm{c}}$, Richard J.F. Bewley ${ }^{\mathrm{d}}$

${ }^{a}$ British Geological Survey, Environmental Science Centre, Keyworth, Nottingham, NG12 5GG, UK

${ }^{\mathrm{b}}$ British Geological Survey, The Lyell Centre, Research Avenue South, Edinburgh, EH14 4AP, UK

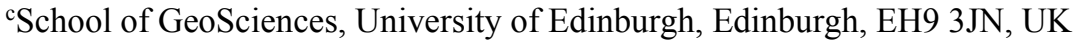

${ }^{d}$ URS Corporation Ltd, Manchester, M1 6HS, UK

*Corresponding author. Tel+44 (0)115936 3017; fax+44 (0)115936 3460. E-mail address: jwrag@bgs.ac.uk 
$\mathrm{As}, \mathrm{Cr}, \mathrm{Pb}$ apportionment Glasgow soils

\begin{abstract}
The chemical composition of soil from the Glasgow (UK) urban area was used to identify the controls on the availability of potentially harmful elements (PHE) in soil to humans. Total and bioaccessible concentrations of arsenic, chromium and lead in 27 soil samples, collected from different land uses, were coupled to information on their solid phase partitioning derived from sequential extraction data. The total element concentrations in the soils were in the range $<0.1-135 \mathrm{mg} \mathrm{kg}^{-1}$ for As; $65-3680 \mathrm{mg}$ $\mathrm{kg}^{-1}$ for $\mathrm{Cr}$ and $126-2160 \mathrm{mg} \mathrm{kg}^{-1}$ for $\mathrm{Pb}$, with bioaccessible concentrations averaging 27,5 and $27 \%$ of the total values respectively. Land use does not appear to be a predictor of contamination, however the history of the contamination is critically important. The CISED (Chemometric Identification of Substrates and Element Distribution) sequential chemical extraction and associated self modelling mixture resolution (SMMR) analysis identified three sample groupings and 16 geochemically distinct phases (substrates). These were related to Fe ( $\mathrm{n}=3), \mathrm{Al}-\mathrm{Si}(\mathrm{n}=2), \mathrm{Ca}(\mathrm{n}=3), \mathrm{P}(\mathrm{n}=1), \mathrm{Mg}(\mathrm{n}=3)$, $\mathrm{Mn}(\mathrm{n}=1)$ and easily extractable $(\mathrm{n}=3)$ which was predominantly made up of $\mathrm{Na}$ and $\mathrm{S}$. Arsenic, $\mathrm{Cr}$ and $\mathrm{Pb}$ were respectively found in 9, 10 and 12 of the identified phases with bioaccessible As predominantly associated with easily extractable phases, bioaccessible $\mathrm{Cr}$ with the $\mathrm{Mg}$-dominated phases and bioaccessible $\mathrm{Pb}$ with both the Mg-dominated and $\mathrm{Al}-\mathrm{Si}$ phases. Using a combination of the UBM to measure the bioaccessibility of PHE and CISED to identify the geochemical sources has allowed a much better understanding of the complexity of PHE mobility in the Glasgow urban environment. This approach can be applied to other urban environments and soil contamination, and made part of land use planning.
\end{abstract}

\title{
Keywords
}

Human health risk assessment, Sequential extraction, CISED, Bioaccessibility, Land Contamination, Metals 
As, $\mathrm{Cr}, \mathrm{Pb}$ apportionment Glasgow soils

There is growing concern about concentrations of potentially harmful elements (PHE) in soil, which may be present as a result of natural geological processes or as a consequence of anthropogenic activities. The latter are particularly important in urban environments where a variety of transport, energy, construction industry and waste disposal functions has resulted in soil pollution. PHE are of interest because of their possible deleterious effects on human health, and include arsenic (As) (Chen et al. 2010), chromium (Cr) (ATSDR 2012) and lead (Pb) (Wright et al. 2008). PHE enter the human body from soil through one of three principal exposure pathways: ingestion, inhalation and dermal contact (Environment Agency 2009b). As such, many countries around the world have regulatory regimes in place to limit the quantity of PHE in soil and restrict human exposure e.g. (DEFRA 2014)).

Deciding whether the risk of adverse health effects from chronic exposure to chemicals in soil is unacceptable often requires a Human Health Risk Assessment (HHRA). One aspect of a HHRA involves comparing representative soil concentrations with regulatory assessment criteria to determine whether a particular land use, e.g. residential is suitable for its intended purpose. In the United Kingdom (UK) these criteria are usually referred to as Generic/Site specific Assessment Criteria (GAC/SSAC) (Environment Agency 2004, 2009b) or Soil Screening Levels (SSL) (DEFRA 2014). According to Nathanail (2005) GAC "should represent contaminant concentrations below which there is no unacceptable risk to human health", these criteria provide a cautious approach to any risk assessment. Exceedance of these criteria does not necessarily mean that land is unsuitable for its intended use, rather that detailed investigation is required to examine the validity of a potential source, pathway, receptor linkage for a given chemical and associated land use (DEFRA 2014; Environment Agency 2009a) resulting in the production of SSAC.

To determine the concentration of metals in soils for HHRA, elemental analysis of PHE in soil, almost regardless of method, is a relatively expedient ( $<10$ days) and low cost $(<£ 50 /$ per sample) way to measure the total amount contained in a sample. However, such analyses do not account for the biological or chemical availability of the elements, thereby potentially overestimating the risk and leading to unnecessary remediation or blighting of land that would otherwise be developable (CIEH, 2009). Biological and chemical availability of soil contaminants to humans are proportional to the total concentration present in a given sample. Human oral bioaccessibility is the concentration of a chemical compound dissolved from the soil into solution within the gastro-intestinal compartment and is potentially available for uptake by absorption (Wragg et al. 2011). Human oral bioavailability is the fraction of a chemical compound in soil that, once solubilised, is absorbed across gastro-intestinal epithelial cells and is available for distribution to internal target tissues and organs (Denys et al. 2012). Assessment criteria derived using bioaccessibility data for the ingestion pathway in the UK, are an effective basis for reducing conservatism in risk assessment, and over the past decade or so have gained broad regulatory acceptance (Environment Agency 2009b; Nathanail et al. 2005). In vivo bioavailability 
data are expensive and raise important ethical issues (Denys et al., 2012; Wragg et al. 2011), so in response, in vitro bioaccessibility tests have been developed, which, although costlier than analysis of the total PHE, assist in providing a surrogate for in vivo bioavailability data. Although either bioavailable or bioaccessible data can be used in risk assessment, these measures do not provide information on the solid phase fractionation of elements in soil (often described as chemical availability). This information is important as it can lead to improvements in the understanding of how and why elements are biologically and chemically accessible, assisting with risk-based land management by providing an additional line of supporting evidence to the decision making process when development of contaminated land for human use is being considered (Denys et al. 2012; Farmer et al. 1999; Wragg and Cave 2012).

The chemical availability of contaminants in soil is often determined using sequential chemical extractions (Cave et al. 2004). Such methods are used to characterize the solid phase fractionation of elements in soils and sediments and use a series of increasingly aggressive reagents (Bacon and Davidson, 2008) or more recently, by some workers (Reis et al. 2014; Wragg and Cave 2012; Wragg et al. 2014a), using a sequence of acid extractions of increasing strength. The elements of interest in soil are distributed amongst a series of physico-chemical phases of the matrix, that can be classed as: 1) exchangeable fraction; 2) specifically adsorbed fraction and those associated with carbonates; 3) $\mathrm{Fe}$ and Mn-oxides; 4) organic matter and sulphides; and 5) mineral lattice (Cave et al. 2004). Sequential extraction methods can generate a large amount of data that needs processing in order to assist with the interpretation of the results. This can require a combination of analytical and statistical techniques to collectively produce results that can be used to describe the soils under investigation. One such method is the Chemometric Identification of Substrates and Element Distributions (CISED) and its associated Self-modelling Mixture Resolution Algorithm (SMMR) (Cave et al. 2004). Bacon and Davidson (2008) provide a review of the CISED method which has been used to assist with understanding the solid phase distribution of elements in soil (Cave et al. 2004; Giacomino et al. 2011) and explain the possible solid phase associations of the bioaccessible portions of a number of PHE in soil including As, cadmium (Cd), Cr, nickel (Ni), Pb and antimony (Sb) (Gal et al. 2007; Gal et al. 2006; Wragg et al. 2014a; Wragg and Cave, 2012; Wragg et al. 2011).

The aim of this study was to determine the solid phase distribution of $\mathrm{As}, \mathrm{Cr}$, and $\mathrm{Pb}$ to improve understanding of the controls on the bioaccessibility of these PHE in Glasgow soils. 


\section{Materials and Methods}

\subsection{Sampling Location}

Glasgow is Scotland's largest city with a population of around 600,000 covering an area of approximately $180 \mathrm{~km}^{2}$ (National Records Scotland 2016). The city has a long history of heavy industry which has left a legacy of polluted soil (Ajmone-Marsan et al. 2008; Davidson et al. 2006; Farmer et al. 1999; Farmer and Lyon 1977; Fordyce et al. 2005; Fordyce et al. 2017; Fordyce et al. 2012; Gibson and Farmer 1983 ; Madrid et al. 2006) that is also typical of many other industrial cities world-wide (Johnson et al. 2011; Sharma et al. 2015). Principal activities that have led to this in Glasgow include mining for coal, minerals or aggregates, and heavy industry such as ship building, steel and iron manufacturing, railway engineering, car manufacturing, transport (particularly the use of leaded petrol during the $20^{\text {th }}$ century), energy generation and, until the 1960s, the world's largest chromite ore processing plant (Farmer et al. 1999; Fordyce et al. 2017; Fordyce et al. 2012). The disposal of chromite ore processing residue (COPR) from the chromite plant to landfill has led to localised pollution with $\mathrm{Cr}$ concentrations of up to $15,600 \mathrm{mg} \mathrm{kg}^{-1}$ reported in soil in Glasgow (Bewley et al. 2001; Farmer et al. 1999).

Fordyce et al. (2017) report ranges in total concentration for As $\left(<0.9-850 \mathrm{mg} \mathrm{kg}^{-1}\right), \mathrm{Cr}(34-5334 \mathrm{mg}$ $\left.\mathrm{kg}^{-1}\right)$ and $\mathrm{Pb}\left(12-9937 \mathrm{mg} \mathrm{kg}^{-1}\right)$ in 2333 urban topsoils collected across the Glasgow conurbation as part of the British Geological Survey (BGS) Geochemical Baseline Survey of the Environment (GBASE) Programme. As a result of urban pollution, median $\mathrm{Cr}\left(102 \mathrm{mg} \mathrm{kg}^{-1}\right)$ and $\mathrm{Pb}\left(125 \mathrm{mg} \mathrm{kg}^{-1}\right)$ concentrations are significantly elevated in urban topsoils relative to rural topsoil medians for Scotland (Cr $41 \mathrm{mg} \mathrm{kg}^{-1}$; Pb $23 \mathrm{mg} \mathrm{kg}^{-1}$; Paterson 2011). Arsenic was not determined in Scottish rural soils (Paterson 2011). Topsoil Cr concentrations are higher than most other UK cities as a result of the history of chromite ore processing in the city (Fordyce et al. 2005; Fordyce et al. 2017). In contrast, Fordyce et al. (2005) report that topsoil As concentrations in Glasgow are lower than other UK cities (median range $\left.10-53 \mathrm{mg} \mathrm{kg}^{-1}\right)$. The median $\mathrm{Pb}$ concentration in Glasgow falls within those reported $\left(40-225 \mathrm{mg} \mathrm{kg}^{-1}\right)$ for the other UK studies considered by Fordyce et al. (2005). Comparison of $\mathrm{As}, \mathrm{Cr}$ and $\mathrm{Pb}$ concentrations in Glasgow soils with HHRA criteria indicated exceedances for Cr. Following possible health concerns about $\mathrm{Cr}$ in particular (Farmer and Jarvis 2009), methods to assess soil bioaccessibility were optimised for $\mathrm{Cr}$ to inform HHRA. These included application of the Unified Barge Method (UBM) (Denys et al. 2012) and CISED (Chemometric Identification of Substrates and Element Distributions) (Cave et al. 2004) methodologies to selected soils from Glasgow. Whilst the primary focus of these investigations was $\mathrm{Cr}$, the bioaccessibilities of $\mathrm{As}$ and $\mathrm{Pb}$ were also determined. The results of the UBM bioaccessibility assessments for $\mathrm{Cr}$ and $\mathrm{Pb}$ have been documented previously (Appleton et al. 2013; Appleton. et al. 2012a and b; Broadway et al. 2010; Farmer et al. 2011). 
As, $\mathrm{Cr}, \mathrm{Pb}$ apportionment Glasgow soils

\subsection{Sample Selection, Collection and Preparation}

\subsubsection{Sample Selection}

The 27 soils used in this study comprised 21 samples selected from those collected in 2001/2002 as part of the BGS G-BASE survey of the Glasgow area (Fordyce et al. 2017; Fordyce et al. 2012) and six collected in 2005 from locations in areas previously identified as at least potentially contaminated with $\mathrm{Cr}$ from chromite ore processing residue (COPR) disposal (Broadway et al. 2010). The 21 samples in the former group were selected on the basis of G-BASE sites where previous X-ray fluorescence (XRF) analysis had shown the total concentration of any one of $\mathrm{Cr}, \mathrm{Pb}$ and $\mathrm{As}$ exceeded the $\mathrm{UK}$ soil assessment criteria adopted at that time for the observed land use (e.g. gardens and recreational land) with a high potential for contact with the human population, especially children. These included one sample in Muirend from a sportsground known to be impacted by COPR waste (Broadway et al. 2010). The locations of and a fuller description of the sampling sites are given in Figure 1 and Table 1, respectively. The $\mathrm{pH}$ of the soils ranged from 3.8 to 7.7 (mean $5.3 \pm 0.8$ ) and the total organic carbon content from $7.7 \%$ to $30.5 \%$ (mean $15.8 \pm 5.6 \%$ ) (Broadway et al. 2010). Samples were collected from sites with six different land uses (Table 1).

\subsubsection{G-BASE Sample Collection}

At each site, a sample comprising a composite of $<2 \mathrm{~mm}$ topsoil from $5-20 \mathrm{~cm}$ depth from the corners and centre of a $20 \times 20 \mathrm{~m}$ square was collected using a hand held Dutch auger and then analysed for its total element concentration according to standard G-BASE procedures (Fordyce et al. 2005; Fordyce et al. 2017). Excess sample material was stored under ambient conditions in the BGS National Geoscience Data Centre. Subsamples of BGS G-BASE archive $<2 \mathrm{~mm}$ topsoil material were selected for the present study and further sieved to $<250 \mu \mathrm{m}$ as this fraction is considered to be the largest fraction that will stick to the hands of children (Denys et al. 2012).

\subsubsection{Cr-contaminated Site Sample Collection}

At each site, a single composite soil sample was collected. A composite sample consisted of three individual flights collected with a hand-held Dutch auger from the corners of a $2 \mathrm{~m}$ equilateral triangle (Broadway et al. 2010; Palumbo-Roe et al. 2005). As with the G-BASE sampling procedure, only the surface soil $(5-20 \mathrm{~cm})$ was collected.

\subsubsection{Sample Preparation}

The soil samples were oven-dried at $35 \pm 2{ }^{\circ} \mathrm{C}$. Each dried coarse sample (including the $21<2 \mathrm{~mm} \mathrm{G}$ BASE samples) was gently disaggregated by hand with a porcelain pestle and mortar to ensure the breakage of aggregates, but not clasts, and the disaggregated sample then sieved to $<250 \mu \mathrm{m}$ for the 
As, $\mathrm{Cr}, \mathrm{Pb}$ apportionment Glasgow soils

determination of human oral bioaccessible concentrations. Sub-samples $(\sim 10 \mathrm{~g})$ of the $<250 \mu \mathrm{m}$ fraction were milled for mixed acid total digestion.

\subsection{Laboratory Analysis}

\subsubsection{Total Element Concentrations}

The total elemental composition of the 27 soils was determined by Inductively Coupled Plasma Optical Emission Spectrometry (ICP-OES) following acid digestion $\left(\mathrm{HNO}_{3} / \mathrm{HF}\right)$ using a modified version of USEPA Method 3052 (USEPA 1995) previously described in full by Broadway et al. (2010). A digestion run consisted of six soil samples (in duplicate), one reference soil, (the Czech Metrological Institute sample number 7002 (CMI 7002)), and a reagent blank. The total element recoveries of CMI 7002 were within $\pm 10 \%$ for $\mathrm{As}, \mathrm{Cr}$, and $\mathrm{Pb}$ and results for blank extractions were all less than the respective detection limit.

\subsubsection{Soil Mineralogy}

X-Ray Diffraction (XRD), using a Bruker-AXS D8 Advance with $\mathrm{Cu} \mathrm{K} \alpha \mathrm{X}$-Ray tube with data identification using DIFRAC ${ }^{\text {plus }}$ EVA software, was used to provide qualitative mineralogical evidence to support the identification of solid phase hosts of PHE in the soils.

\subsubsection{Human Oral Bioaccessible PHE}

The UBM (Denys et al. 2012), an in vitro method to simulate physico-chemical conditions in the human gut, was used to measure the concentration of soil PHE that is accessible to humans after accidental soil ingestion. Simulation of the gut is carried out by way of a three-stage sequential extraction that approximates physiologically and chemically relevant conditions in the human gastro-intestinal system (e.g. temperature, transit times though the gut, gut fluid composition and $\mathrm{pH}$ ). The UBM procedure used to determine PHE bioaccessibility in this study has been previously fully documented (Broadway et al. 2010; Farmer et al. 2011). Other studies (Okorie et al. 2011; Pelfrene et al. 2011; Reis et al. 2014; Roussel et al. 2010; Wragg et al. 2014a; Wragg and Cave 2012; Wragg et al. 2011) have applied the methodology across Europe and North America as it has been developed and validated. .

\subsubsection{CISED Extractable PHEs}

The number and composition of soil geochemical phases, potentially hosting the PHE of interest (As, $\mathrm{Cr}, \mathrm{Pb}$ ), in the 27 soils were identified using the CISED method. The CISED is a non-specific sequential extraction method that uses increasing concentrations of Aqua Regia (AnalaR grade: $70 \% \mathrm{HCl}: 30 \%$ $\mathrm{HNO}_{3}$ ) to extract the geochemical phases of a soil and identify the distribution of PHE of interest (e.g. 
$\mathrm{As}, \mathrm{Cr}$ and $\mathrm{Pb}$ ) therein. The practical application of the CISED has been previously described by Wragg and Cave (2012). The ease of extraction of individual geochemical phases is related to their chemical composition and the stage in the CISED where it is extracted (e.g. at high or low acid strength), providing an indication of the environmental mobility of (for this work) As, $\mathrm{Cr}$ and $\mathrm{Pb}$. The advantages that this non-specific extraction affords over traditional sequential extractions, its application to soil samples and the methodology for naming the geochemical phases have been previously described in full (Cave et al. 2004). For this study, a total of 378 extracts were generated (14 extracts per soil ( $\mathrm{n}=27$ ) and analysed for $>20$ elements. The resulting multi-element data are resolved into the individual geochemical phases, some of which act as hosts for PHE, using a SMMR (self-modelling mixture resolution) algorithm, programmed and executed in the Matlab@ programming language (Cave 2008).

\subsection{Data Presentation and Statistical Analysis}

To derive a common set of soil components for the Glasgow area, the SMMR algorithm was applied to a combined multi-element dataset for the 27 soils, rather than resolving the data for each individual soil (Wragg and Cave 2012; Wragg et al. 2014b). The CISED results are summarised by plotting the amount of each component in the different test soils with the stage in the sequential extraction process that the component was released and, separately, identification and quantification of the amount of PHEs of interest in each component. Cluster analysis was undertaken (section 2.4), using Matlab (C) to rationalise and visualise the number of identified components into broader physico-chemical groupings (Clusters) in a consistent manner to simplify discussion and visualisation (Wragg et al. 2014b). Statistical analysis and subsequent figure generation was carried out using Matlab (C (Figure 6) and R (R Core Team 2016) (Figures 2,3,4,7,8 and 9).

\section{Results and Discussion}

\subsection{Soil Mineralogy}

XRD analysis of the soils identified a number of common soil-forming constituents: quartz, anorthite, kaolinite, calcite, hematite, chlorite, muscovite, goethite, dickite and greenalite. Each individual sample contained a varied combination of these reflecting underlying soil parent materials and land use (Broadway 2008). Mullite, a rare mineral used as a refractory material e.g. in furnace linings, was found in Sample 3. The source of this mineral is unknown as it was collected from a residential grass area/road verge with no previous industrial land use.

\subsection{Total As, $\mathrm{Cr}$ and $\mathrm{Pb}$ Concentrations in Glasgow Soils}

The results of elemental analysis in the soils have been previously described (Appleton et al. 2012a and b; Broadway et al. 2010; Farmer et al. 2011). In summary, the total elemental concentrations in the soils 
were in the range $<0.1-135 \mathrm{mg} \mathrm{kg}^{-1}$ for As; $65-3680 \mathrm{mg} \mathrm{kg}^{-1}$ for $\mathrm{Cr}$ and $126-2160 \mathrm{mg} \mathrm{kg}^{-1}$ for Pb (Table 1). In statistical analysis it is generally accepted that a minimum of five samples are required to establish a data distribution (Stockburger 2001). In the current dataset, several land use classes contained less than five soil samples and the small sample set precluded the calculation of robust estimates of statistically significant relationships between soil element concentration and land use. However, from visual inspection of the reported element concentrations in Table 1 and Figure 2, it is clear that the highest total $\mathrm{As}$ and $\mathrm{Pb}$ concentrations are recorded in some of the residential grass areas, sports ground and domestic garden soils. This may reflect the presence of artificial ground used for landscaping residential grass areas and sports grounds and, in the case of $\mathrm{Pb}$, the proximity to road verges in several of the residential grass areas. The higher values in some garden soils are possibly the result of the application of domestic coal ash as a soil conditioner (Fordyce et al. 2017; Fordyce et al. 2012).

Highest total-Cr concentrations are recorded in samples 20 and 24 collected from sports grounds in Rutherglen and Muirend and sample 19 from an industrial site in Rutherglen, all within areas known to be impacted by COPR waste (Table 1 and Figure 2). (Broadway et al. 2010) reported $\mathrm{Cr}(\mathrm{VI})$ concentrations of 1485,171 and $23 \mathrm{mg} \mathrm{kg}^{-1} \mathrm{Cr}(\mathrm{VI})$, respectively in these soils, indicating the strong influence of COPR, particularly in Samples 20 and 24, with $\operatorname{Cr}(\mathrm{VI})$ amounting to $40 \%$ and $26 \%$, respectively, of the total $\mathrm{Cr}$.

\subsection{Human oral bioaccessible As, Cr and Pb by the UBM}

The bioaccessibility of $\mathrm{Cr}, \mathrm{Pb}$ and As respectively in the Glasgow soils used in this study has been previously described in detail (Appleton et al. 2013; Appleton et al. 2012a; Broadway et al. 2010; Farmer et al. 2011). In general, higher bioaccessible $\mathrm{As}, \mathrm{Cr}$ and $\mathrm{Pb}$ concentrations are reported in samples with a greater total concentration of these elements. Bioaccessible $\mathrm{As}, \mathrm{Cr}$ and $\mathrm{Pb}$ are referred to as $\mathrm{B}-\mathrm{As}, \mathrm{B}-\mathrm{Cr}$ and $\mathrm{B}-\mathrm{Pb}$ in the following discussion.

Where the data were above the instrumental limit of detection (Cr: 3 and $5 \mathrm{mg} \mathrm{kg}^{-1}$ in the stomach and intestine compartments respectively, As: 6 and $5 \mathrm{mg} \mathrm{kg}^{-1}$ in both compartments respectively and $\mathrm{Pb}: 5$ $\mathrm{mg} \mathrm{kg}{ }^{-1}$ for both compartments), the bioaccessible fraction (BAF) of each PHE in the soils was calculated as a percentage of the total concentration using the highest value obtained from the G or GI phase (Table 2). The mean \% BAF of As (GI) was 35.6 $\pm 11.1 \%$ ranging from $16-48 \%, 7.6 \pm 7.6 \%$ (3$31 \%$ ) for $\mathrm{Cr}(\mathrm{G})$ and $52 \pm 13.4 \%$ (23-77\%) for $\mathrm{Pb}(\mathrm{G})$. Analysis of variance on the three BAF populations shows a significant difference between all three elements.

These results are broadly comparable with those reported in a separate study (Sialelli et al. 2010) for 20 Glasgow soils (Cr intestine phase 5 - 29\%; Pb stomach phase 21 -44\%) despite differences in sampling 
approaches (including sample locations) and extraction methodologies compared to this study. The $\%$ BAF is relative to the total and bioaccessible concentrations. Sialelli et al. (2010) used a $\mathrm{HCl}: \mathrm{HNO}_{3} 3: 1$ acid digestion to determine the total elemental PHE concentration, which is less aggressive than the $\mathrm{HF} / \mathrm{HNO}_{3}$ digestion used here (resulting in possible lower total concentrations) and a bioaccessibility method with different $\mathrm{pH}$, chemical composition, extraction time and agitation methods compared to the UBM.

Bioaccessible soil PHE concentration is shown in Figure 3 stratified by land use type. Detectable B-As is present in only nine of the samples, mainly those from residential grass area and sports ground land use types. A river walkway in an industrial site (Sample 21), samples collected close to road verges from a domestic garden (Sample 9) and a school playground (Sample 13) (Table 2) also contain quantifiable B-As. Bioaccessible As was not detected in many parkland soils and the soil collected from industrial land in Rutherglen (Sample 20; Table 2). Bioaccessible $\mathrm{Pb}$ was measurable in all the soil samples, with highest values reported in residential grass area soils over artificial ground and in a domestic garden (Sample 7; Table 2). The higher B-As and B-Pb in residential garden and grass areas reflect the higher total content of these elements in these samples. Detectable B-Cr was reported in 15 of the soils only, from a variety of land use types (Table 2). The highest B-Cr was recorded in the two soils impacted by COPR waste from Rutherglen and Muirend (Samples 20 and 24; Table 2 and Figure 3). It was demonstrated that this was related to the greater $\mathrm{Cr}(\mathrm{VI})$ content in these samples (Broadway et al. 2010). Comparison of the \% BAF results between the samples (Table 2 and Figure 4) indicates that a greater proportion of $\mathrm{Cr}$ is bioaccessible in these two COPR-influenced soils, than in soils from other land use types. With the exception of these two samples, the \% BAF $\mathrm{Cr}(5 \pm 2 \%)$ is similar in the other soils regardless of land use type. Similarly, there are no consistent relationships between \% BAF As and land use or between land use and the presence or absence of detectable soil B-As or B-Cr (Table 2 and Figures 3 and 4). The \% BAF for Pb shows a similar range over all land use types (Table 2 and Figure 4).

The results suggest that with the exception of the COPR-impacted samples, land use per se is not a controlling factor on element bioaccessibility. To better understand likely influences on element bioaccessibility in the soils, the CISED approach was adopted to determine the likely solid phases hosting $\mathrm{As}, \mathrm{Cr}$ and $\mathrm{Pb}$ in the soils and their relative mobility.

\subsection{Chemometric Identification of Substrates and Element Distributions}

The summed concentrations of $\mathrm{As}, \mathrm{Cr}$ and $\mathrm{Pb}$ associated with the 14 extracts of the CISED (per soil) were compared to the total concentrations to calculate element recovery information and used as a proxy for element mobility: As, $\mathrm{Cr}$ and $\mathrm{Pb}$ recoveries were $12-100 \%, 5-85 \%$ and $66-100 \%$, respectively. 
As, $\mathrm{Cr}, \mathrm{Pb}$ apportionment Glasgow soils

The mobility range indicates that all three PHE are mobile across the samples under investigation, with $\mathrm{Pb}$ mobility being $>50 \%$ for all of the soils.

To identify the physico-chemical component hosts of $\mathrm{As}, \mathrm{Cr}$ and $\mathrm{Pb}$ in the 27 samples the SMMR (developed by (Cave 2008) was applied to the whole data set (rather than on an individual sample basis) in a similar manner to previous studies (Wragg and Cave 2012; Wragg et al. 2014b). The data matrix comprised of 378 rows of extraction data (14 extracts, 27 soils) for 21 elements. Initial data assessment of the SMMR outputs for the 27 test soils indicated three distinct groupings of samples, based on the composition of the geochemical phases and the acid concentration required for their removal from the soils. Table 3 provides a summary of the samples in each cluster grouping and the mean total concentration $\left(\mathrm{mg} \mathrm{kg}^{-1}\right)$ of $\mathrm{As}, \mathrm{Cr}$ and $\mathrm{Pb}$ in each grouping.

Group 1 contains 8 samples whereas Group 2 contains 18 samples. Group 3 comprises the COPRimpacted sample 20 collected from a known COPR waste site in Rutherglen only (Table 3). The geochemistry of this sample is clearly distinct from the rest of the samples in the SMMR. Groups 1 and 2 both contain soils that were collected across the city. There is no clustering of soils from particular sections of the city. Both groups contain soil samples that were collected over Devonian sandstone, Carboniferous sandstone, Carboniferous Limestone and Coal Measures geology. However, Group 2 contains four samples collected over the Clyde Plateau Volcanic Formation. Both groups contain soils from a range of land use types and there are no obvious differences in soil texture as reported during collection or mineralogical composition as measured by XRD analysis between the two groups.

In terms of the element concentrations in each group, As, $\mathrm{K}, \mathrm{Na}$ and TOC show similar ranges between the two groups of soil samples. Group 2 soils have higher $\mathrm{Al}, \mathrm{Ba}, \mathrm{Ca}, \mathrm{Cr}, \mathrm{Cu}, \mathrm{Fe}, \mathrm{Mn}, \mathrm{Ni}, \mathrm{S}, \mathrm{V}, \mathrm{Zn}$ and pH but lower P and Si than Group 1. This may reflect the inclusion of COPR samples from Rutherglen (sample 19) and Muirend (sample 24) in particular (which is known to be COPR impacted) in this group, as the COPR is highly alkaline with higher $\mathrm{Ca}$ and metal contents. The higher $\mathrm{Al}, \mathrm{Fe}, \mathrm{Mn}$ and $\mathrm{V}$ and lower Si in this group may also reflect the geochemistry of soils collected over the Clyde Plateau Volcanic Formation. However, with the exception of the COPR-impacted sample 20 in Group 3, clear spatial, geological, land use or mineralogical reasons for the SMMR groups are difficult to discern.

Comparison of mean total $\mathrm{As}, \mathrm{Cr}$ and $\mathrm{Pb}$ concentration in Groups 1 and 2 shows that higher values are related to the Group 2 soils. The single soil in Group 3 (Sample 20; Table 3) is distinguished from the Group 2 soils because of the higher total concentration of As and $\mathrm{Cr}$ compared to the average for the two samples in Group 2, whereas the opposite is true for the total concentration of $\mathrm{Pb}$. 
The SMMR was individually applied to CISED data matrices after separation into the three groupings identified by the cluster algorithm (Table 3). The output information obtained from the separate applications resulted in 7, 17 and 5 geochemical phases for Groups 1-3 respectively, each with its own extraction profile (amount of the component at extraction points 1-14). The geochemical phases for each Group were named according to the previously described procedure (Cave et al. 2015; Wragg et al. 2014b), which uses the elemental composition (where an element makes up $>10 \%$ of the physicochemical composition). Because the number of identified geochemical phases in each Group, their composition and the amount of each in each soil (extracts 1-14) is different, it is difficult to directly compare the information. To aid comparison of information hierarchical cluster analysis, using a previously described method (Cox et al. 2013; Wragg and Cave 2012; Wragg et al. 2014b), was applied to the CISED SMMR data to derive a consistent number of geochemical phases (for further discussion named Clusters) across the set of 27 sample soils. Figure 5 is an overview of the data processing, which is described in detail below. The composition ( $\mathrm{Al}, \mathrm{Ca}, \mathrm{Fe}, \mathrm{K}, \mathrm{Mg}, \mathrm{Mn}, \mathrm{Na}, \mathrm{P}, \mathrm{S}, \mathrm{Si}, \mathrm{As}, \mathrm{Cr}, \mathrm{Ni}, \mathrm{Pb}$ ) and extraction profile information for each geochemical phase in each soil was collated, producing a data matrix of 366 rows (one for each geochemical phase in the soils (Group 1-3)) and 28 columns (elemental composition information and the amount of each geochemical phase (extracts 1-14)). The new collated data matrix was subjected to hierarchical clustering, where the data were mean-centred and scaled with Euclidean distance, and linkage was determined using Ward's method. The output, in the form of a colourmap (Figure 6), was used as a visual aid to identify clusters of similar geochemical phases with respect to their elemental compositions (\%) and extraction position where the geochemical phases that make up the clusters were extracted during the CISED method (1-14).

\subsubsection{Cluster Identification}

Sixteen geochemically distinct clusters were identified in the data set, using the elemental composition information from Figure 6 (supported by XRD information) and ordered in relation to their ease of extractability (right hand side of Figure 6). Clusters were named according to the position in the CISED where they were observed and their elemental composition, e.g. $\mathrm{C} 1$ residual pore salts, observed at extraction points 1 and 2 containing $\mathrm{Na}$ and $\mathrm{S}$; $\mathrm{C}$, dominated by $\mathrm{Ca}$ and extracted on the first addition of Aqua Regia (0.01 M). The identified clusters were residual pore water (C1), organic (C2), Mgdominated (C4, 14 and 15), and Ca-dominated (C12, 13 and 16). A detailed description of the 16 clusters is available in the supplementary information (Table S). Table 4 summarises the median PHE distribution ( $\mathrm{mg} \mathrm{kg}^{-1}$ and $\%$ of the total CISED extractable) within the 16 clusters, re-ordered according to their extraction position in the CISED (columns 1-14 of Figure 6).

The clusters were grouped, for example, into Fe- or Al-dominated and their abundance calculated. This information was used to aid the identification process. Figures 7 and 8 summarise respectively the 
abundance $\left(\mathrm{mg} \mathrm{kg}^{-1}\right)$ of each cluster type across the whole data set as box and whisker plots and the abundance of each cluster, where present, in the three sample groupings identified in section 2.4. In general, the most abundant clusters are those associated with $\mathrm{Fe}, \mathrm{Al}, \mathrm{Ca}, \mathrm{Mg}$ and $\mathrm{P}$, whereas soil pore water, exchangeable, organic and Mn-dominated clusters are less abundant.

As:

The cluster classed as organic (C2) was the primary host of As $\left(5.03 \mathrm{mg} \mathrm{kg}^{-1}, 34.6 \%\right.$ of the total extractable As). On the breakdown of organic components (by the addition of $\mathrm{H}_{2} \mathrm{O}_{2}$ ), any chelated inorganic constituents can be released into solution, especially in the presence of metal ions such as amorphous Al or Fe oxyhydroxides (Pfeifera et al. 2004). The relatively high As concentration in the combined easily extractable clusters (residual pore water + organic + exchangeable) indicates the greater mobility of As compared to $\mathrm{Cr}$ and $\mathrm{Pb}$ (Table 4).

Cr:

A study by Davidson et al. (2006) used the 4-step Community Bureau Reference sequential extraction method on Glasgow soils. The methodology identifies water/acid soluble and exchangeable, reducible, oxidisable and residual soil phases. Davidson et al. (2006) reported that in general, the Cr was partitioned across all extractable phases, with the highest proportion of $\mathrm{Cr}$ associated with the residual fraction. Table 4 indicates that a Mg-dominated phase (C15) was a significant host of $\mathrm{Cr}(88 \%)$ in this study using the CISED method, which unlike the study by Davidson et al. (2006), was focussed on soils impacted by COPR waste. This phase was extracted later in the CISED extraction using high concentrations of Aqua Regia $(1.0 \mathrm{M}-5.0 \mathrm{M})$, which, is comparable to the $4^{\text {th }}$ step BCR residual phase and is therefore in agreement with previous findings.

$\mathrm{Pb}$ :

In a similar study to Davidson et al. (2006) Gibson and Farmer (1986) adopted a 6-step scheme based on modifications of several published methods (with phases defined as exchangeable; carbonate bound; easily reducible (Mn -oxides and hydroxides); moderately reducible (Fe-oxides); organic; and residual. These authors found that $\mathrm{Pb}$ was preferentially partitioned into the moderately reducible fraction $(51 \%)>$ with the remainder in the organic (19\%), residual (17\%), combined exchangeable and carbonate bound (13\%), and easily reducible (0 4\%) fractions of Glasgow soils. Similarly to Gibson and Farmer (1986), Davidson et al. (2006) found that a large proportion of $\mathrm{Pb}$ was in the reducible phase. This study associated $\mathrm{Pb}$ with the alumino-silicate phases (48\%) and the Mg-dominated phase (41\%) (Table 4). Since the BCR steps are methodologically defined and the CISED components are defined by the chemical composition of the extracts it is not always possible to make a direct comparison between the two methods. In this instance, however, the $\mathrm{BCR}$ suggests that $\mathrm{Pb}$ is associated with the reducible phase, 
usually linked to Fe/Mn oxides, whereas the CISED method suggests that Fe/Mn oxides are not the main host for $\mathrm{Pb}$ in the Glasgow soils.

\subsection{Relationship between distribution of PHE and bioaccessibility}

Identification of the sources of bioaccessible PHE in the soils from Glasgow used the same approach as in other similar studies (Cox et al. 2013; Palumbo-Roe et al. 2005; Wragg and Cave 2012), i.e. by relating the cumulative PHE fractionation (row $\mathrm{A}-\mathrm{C}$ for $\mathrm{As}, \mathrm{Cr}$ and $\mathrm{Pb}$ ) in the identified clusters (116)to the bioaccessibility data from the UBM seperated by the sample groupings (Figure 9). The position that the cumulative extracted PHE is intersected by the bioaccessibility of each PHE gives an indication of the physico-chemical clusters that have been dissolved/digested in the UBM and are likely to be the main source of the bioaccessible PHE.

Comparison of $\mathrm{As}, \mathrm{Cr}$ and $\mathrm{Pb}$ bioaccessibility (rows $\mathrm{A}-\mathrm{C}$ respectively) within the three individual sample groups (Figure 9) shows that:

- Bioaccessible As in all samples in the three groups (Figure 9, row A left to right) is associated with the more easily extractable clusters (Groups 1 and 3: Cluster 1 - Cluster 5 identified in section 2.4 and supplementary table S1 as Residual Pore Salts, Organic, Exchangeable, Mgdominated, Ca-Mg carbonate); Group 2: Cluster 1 (Residual Pore Salts).

- Cr bioaccessibility is a result of dissolution of $\mathrm{Cr}$ (Figure 9 row B left to right) present in all of the identified Cr-bearing clusters:

o Cr bioaccessibility in the samples from Group 1 is a result of the digestion/dissolution of the same easily extractable clusters as for As (Clusters 1-5), along with Clusters 610 (see Table 4 for identification). Because the bioaccessibility intersects the cumulative extracted $\mathrm{Cr}$ between Clusters 15 (Mg-dominated) and 16, one of the Fedominated clusters, it is likely that partial dissolution of Cluster 16 may also be a source of bioaccessible $\mathrm{Cr}$ (Clusters 11-15 do not act as hosts for $\mathrm{Cr}$ ).

o Figure 9 indicates that bioaccessible $\mathrm{Cr}$ in Group 2 (row B, column 2) is a result of the dissolution of clusters $1-11$. These comprise the easily extractable (Clusters $1-3$ ), Mg-dominated (Cluster 4), Ca-dominated (Clusters 5 - 7), Alumino silicates (Clusters 8 and 9), Mn- and P-dominated (Clusters 10 and 11), and partial dissolution of Cluster 12 (Fe-dominated).

o Bioaccessible $\mathrm{Cr}$ in Group 3, a sample from Rutherglen contaminated by COPR with high ca. $3600 \mathrm{mg} \mathrm{kg}^{-1}$ total $\mathrm{Cr}$ (Table 1) is a result of dissolution of $\mathrm{Cr}$ associated with all Clusters but mainly from Cluster 15 (see Table 4). 
- For Groups 1 and 2 (row $\mathrm{C}$ in Figure 9) the bioaccessible $\mathrm{Pb}$ results from the dissolution of Clusters 1 - 8 (easily extractable, carbonates, and alumina silicates) and partial dissolution of Cluster 9 (alumina silicate, Table 4) with Group 3 associated with the dissolution of $\mathrm{Pb}$ from Clusters 1-14 and partial dissolution of 15 (the Mg-dominated cluster at higher acid concentrations than Cluster 14).

\section{Conclusions}

A wide range of total PHE concentrations were observed in 27 topsoil samples collected from a variety of land uses across Glasgow that included 7 samples from areas impacted by COPR waste. The average total concentrations of $\mathrm{As}, \mathrm{Cr}$ and $\mathrm{Pb}$ were 21.9 (2 - 135), 270 (65 - 3680) and 660 (147 - 1340) mg $\mathrm{kg}^{-1}$ respectively.

The measured oral bioaccessibility of $\mathrm{As}, \mathrm{Cr}$ and $\mathrm{Pb}$ in the soils was in general much lower than the total concentration. The average percentage of the total concentration was 37.5, 7.6 and 52\% for $\mathrm{As}, \mathrm{Cr}$ and $\mathrm{Pb}$ respectively; however, the \% Cr bioaccessibility was significantly higher in the COPR impacted soils. With the exception of the COPR impacted soils, no consistent relationships between the bioaccessible $\mathrm{As}, \mathrm{Cr}$ and $\mathrm{Pb}$ and land use per se are evident from this study, however this is likely to be a reflection of the limited number of samples in the study.

Using the CISED extraction methodology three distinct groupings of samples were identified. Comparison of the average total PHE concentrations in the 3 groups of samples shows the same trend for As and $\mathrm{Cr} \mathrm{Gp} 1<\mathrm{Gp} 2<\mathrm{Gp} 3$, whereas the total concentration of $\mathrm{Pb}$ was greatest for $\mathrm{Gp} 2(>\mathrm{Gp} 3>\mathrm{Gp} 1)$.

Subsequent sample clustering and the associated data processing techniques identified a total of 16 geochemically distinct clusters acting as hosts of $\mathrm{As}, \mathrm{Cr}$ and $\mathrm{Pb}$ in soils collected from Glasgow. Each of the clusters had varying degrees of environmental mobility. Nine of the clusters act as host for As, with 12 and 10 clusters acting as hosts of $\mathrm{Cr}$ and $\mathrm{Pb}$ respectively. In general, each PHE had some association with the Fe-, Mg-, P-, Al-Si- and P-dominated and carbonate clusters.

The bioaccessibility of As in Glasgow soils is controlled by the dissolution of the more mobile clusters (1-5; easily extractable and Ca-dominated). When the data set is taken as a whole $\mathrm{Cr}$ bioaccessibility is, dependent on the individual sample groupings, related to all of the clusters identified for the Glasgow soils. Bioaccessible Cr, in the one sample used as the basis for Group 3 (sample 20), the most impacted by COPR and with the highest total $\mathrm{Cr}$ content, is controlled by the solubilisation of $\mathrm{Cr}$ principally associated with all cluster $15 \mathrm{Mg}$-dominated). Bioaccessible $\mathrm{Pb}$ is associated with a range of clusters 
As, $\mathrm{Cr}, \mathrm{Pb}$ apportionment Glasgow soils

from easily extractable to moderately extractable mobile (easily extractable, carbonates, clay and Mgdominated).

This study highlights the variation of total and bioaccessible PHE concentration across Glasgow. In particular, the differences between land use types, sampling location and contamination sources, highlight the potentially hazardous nature of some soils in relation to their current and potential future land uses. However, land use does not appear to be a predictor of contamination, but is closely linked to understanding the historical disposal of COPR in Glasgow.

Using a combination of the UBM to measure the bioaccessibility of PHE and CISED to identify the geochemical sources has allowed a much better understanding of the complexity of PHE mobility in the Glasgow urban environment. This approach can be applied to other urban environments and soil contamination scenarios.

Acknowledgements: We thank the University of Edinburgh (UoE), British Geological Survey (BGS) and Environmental Development and Educational Network (EDEN) for funding Andrew Broadway's $\mathrm{PhD}$ research studentship and costs. Lorna Eades and Megan Reid, both UoE, are thanked for fieldwork, laboratory and analytical assistance as are the BGS staff and student volunteer workers who collected the G-BASE samples used in this study. This paper is published with the permission of the Executive Director of the BGS. 


\section{References}

Ajmone-Marsan, F, Biasioli, M, Kralj, T, GrČman, H, Davidson, C M, Hursthouse, A S, MADRID, L, AND RODRIGUES, S. 2008. Metals in particle-size fractions of the soils of five European cities. Environmental Pollution, Vol. 152, 73-81. http://dx.doi.org/10.1016/j.envpol.2007.05.020

ApPleton, J D, CAVE, M R, PALUMBO-Roe, B, AND WRAGG, J. 2013. Lead bioaccessibility in topsoils from lead mineralisation and urban domains, UK. Environmental Pollution, Vol. 178, 278-287. 10.1016/j.envpol.2013.03.028

ApPlETON, J D, CAVE, M R, AND WRAGG, J. 2012a. Anthropogenic and geogenic impacts on arsenic bioaccessibility in UK topsoils. Science of the Total Environment, Vol. in Press.

APPLETON, J D, CAVE, M R, AND WRAGG, J. 2012b. Modelling lead bioaccessibility in urban topsoils based on data from Glasgow, London, Northampton and Swansea, UK. Environmental Pollution, Vol. 171, 265-272. 10.1016/j.envpol.2012.06.018

ATSDR. 2012. Toxicological Profile for Chromium. Agency for Toxic Sustances and Disease Registry. Available from https://www.atsdr.cdc.gov/toxprofiles/tp7.pdf.

BACON, J R, AND DAVIDSON, C M. 2008. Is there a future for sequential chemical extraction? Analyst, Vol. 133, 25-46. $<$ Go to ISI $>$ ://000251684300012

Bewley, R J F, JefFries, R, WATSOn, S, AND GRANGer, D. 2001. An Overview of Chromium Contamination Issues in the South-East of Glasgow and the Potential for Remediation. Environmental Geochemistry and Health, Vol. 23, 267-271. 10.1023/a:1012261432256

BROADWAY, A. 2008. Development of Methodologies for Determination of the Human Bioaccessibility of Chromium and other Elements in Glasgow Soil. . University of Edinburgh.

Broadway, A, CAVE, M R, WragG, J, Fordyce, F M, BEWLey, R J F, Graham, M C, NGWENya, B T, AND FARMER, J G. 2010. Determination of the bioaccessibility of chromium in Glasgow soil and the implications for human health risk assessment Science of the Total Environment, Vol. 409, 267-277. doi:10.1016/j.scitotenv.2010.09.007

CAVE, M. 2008. The use of self modelling mixture resolution methods for the interpretation of geochemical data sets British Geological Survey, IR/08/035.

CAVE, M, WraGG, J, GOWING, C, AND GARDNER, A. 2015. Measuring the solid-phase fractionation of lead in urban and rural soils using a combination of geochemical survey data and chemical extractions. Environmental Geochemistry and Health, 1-12.

CAVE, M R, MiLODOWSKI, A E, AND Friel, E N. 2004. Evaluation of a method for Identification of Host Physico-chemical Phases for Trace Metals and Measurement of their Solid-Phase Partitioning in Soil Samples by Nitric Acid Extraction and Chemometric Mixture Resolution. Geochemistry: Exploration, Environment, Analysis, Vol. 4, 71-86.

Chen, C-L, Chiou, H-Y, Hsu, L-I, Hsueh, Y-M, Wu, M-M, AND Chen, C-J. 2010. Ingested arsenic, characteristics of well water consumption and risk of different histological types of lung cancer in northeastern Taiwan. Environmental Research, Vol. 110, 455-462. http://dx.doi.org/10.1016/j.envres.2009.08.010

CIEH. 2009. Professional Practice Note: Reviewing human health risk assessment reports invoking contaminant oral bioavailability measurements or estimates, http://www.iaeg.info/portals/0/Content/Commissions/Comm20/CIEH_PPN_Bioavailability_Final_Jun e09.pdf.

Cox, S, Chelliah, M M, McKinley, J, Palmer, S, Ofterdinger, U, Young, M, Cave, M, and WRAGG, J. 2013. The importance of solid-phase distribution on the oral bioaccessibility of Ni and Cr in soils overlying Palaeogene basalt lavas, Northern Ireland. Environmental Geochemistry and Health, Vol. 10.1007/s10653-013-9539-6, 1-15. 10.1007/s10653-013-9539-6

DaVidson, C M, Urquhart, G J, AJMone-Marsan, F, Biasioli, M, da Costa Duarte, A, DíazBARRIENTOS, E, GrČMAN, H, HOSSACK, I, HuRSTHOUSE, A S, MADRID, L, RODRIGUES, S, AND ZUPAN, M. 2006. Fractionation of potentially toxic elements in urban soils from five European cities by means of a harmonised sequential extraction procedure. Analytica Chimica Acta, Vol. 565, 63-72. http://www.scopus.com/inward/record.url?eid=2-s2.0-

33646020081\&partnerID=40\&md5=aed800daf8854dafe3c8475e000cb2af 
DEFRA. 2014. Development of Category 4 Screening Levels for Assessment of Land Affected by Contamination. Department for Environment, Food and Rural Affairs, Policy Companion Document SP1010. (London).

Denys, S, Caboche, J, Tack, K, Rychen, G, WragG, J, CaVe, M, Jondreville, C, and Feidt, C. 2012. In Vivo Validation of the Unified BARGE Method to Assess the Bioaccessibility of Arsenic, Antimony, Cadmium, and Lead in Soils. Environmental Science \& Technology, Vol. 46, 6252-6260. 10.1021/es3006942

EnVIRonment AgEnCY. 2004. Model Procedures for the Management of Land Contamination, CLR 11. Bristol, Environment Agency.

EnVironment Agency. 2009a. Contaminated Land Exposure Assessment Soil Guideline Values. Environment Agency (Bristol).

ENVIRONMENT AGENCY. 2009b. Updated technical background to the CLEA model. Environment Agency (England and Wales), SC050021/SR3 (Bristol). Available from http://publications.environment-agency.gov.uk/pdf/SCHO0508BNQW-e-e.pdf.

FARMER, J G, BRoAdWAY, A, CAVE, M R, WragG, J, Fordyce, F M, GRAHAM, M C, NGWENya, B T, AND BEWLEY, R J F. 2011. A lead isotopic study of the human bioaccessibility of lead in urban soils from Glasgow, Scotland. Science of the Total Environment, Vol. 409, 4958-4965. http://dx.doi.org/10.1016/j.scitotenv.2011.08.061

Farmer, J G, Graham, M C, Thomas, R P, Licona-Manzur, C, Paterson, E, CAmpbell, C D, Geelhoed, J S, Lumsdon, D G, Meeussen, J C L, Roe, M J, Conner, A, FAllick, A E, ANd Bewley, R J F. 1999. Assessment and modelling of the environmental chemistry and potential for remediative treatment of chromium-contaminated land. Environmental Geochemistry and Health, Vol. 21, 331-337. http://www.scopus.com/inward/record.url?eid=2-s2.0$0033512419 \&$ partnerID $=40 \& \mathrm{md} 5=$ ffdab7070c05892d b631ff51ef8750c0

FARMER, J G, AND JARVIS, R. 2009. Strategies for improving human health in contaminated situations: a review of past, present and possible future approaches. Environmental Geochemistry and Health, Vol. 31, 227-238. 10.1007/s10653-008-9209-2

FARMER, J G, AND LYON, T D B. 1977. Lead in glasgow street dirt and soul. Science of the Total Environment, Vol. 8, 89-93. http://dx.doi.org/10.1016/0048-9697(77)90064-X

FordyCE, F M, BROWN, S E, ANDER, E L, RAWLINS, B G, O'DONNELl, K E, Lister, T R, BREWARD, N, AND JOHNSON, C C. 2005. GSUE: Urban geochemical mapping in Great Britain. Geochemistry: Exploration, Environment, Analysis, Vol. 5, 325-336. http://www.scopus.com/inward/record.url?eid=2s2.0-27744530719\&partnerID $=40 \& \mathrm{md} 5=4 \mathrm{~b} 50 \mathrm{e} 7 \mathrm{f} 55 \mathrm{efc} 234 \mathrm{e} 0 \mathrm{bb} 66 \mathrm{~b} 4 \mathrm{a} 0 \mathrm{fa} 1 \mathrm{~d} 8 \mathrm{~d} 2$

FORDYCE, F M, EVERETT, P A, BEARCOCK, J M, LISTER, T R, AND 2017. Soil metal concentrations in the Clyde Basin, Scotland, UK: implications for land quality. . Transactions of the Royal Society of Edinburgh, Vol. This Volume.,

Fordyce, F M, Nice, S E, Lister, T R, Dochartaigh, B O E, COOPer, R, Allen, M, INGHAM, M, GOWING, C, VICKERS, B P, AND SCHEIB, A. 2012. Urban Soil Geochemistry of Glasgow - Main Report. Land Use Planning and Development Programme Open Report OR/08/002. (British Geological Survey, Edinburgh).

GAL, J, HuRsthouse, A, AND CUTHBERT, S. 2007. Bioavailability of arsenic and antimony in soils from an abandoned mining area, Glendinning (SW Scotland). Journal of Environmental Science and Health Part A, Vol. 42, 1263 - 1274. http://www.informaworld.com/10.1080/109345207014355585

GAL, J, HuRsthouse, A S, AND CUTHBERT, S J. 2006. Chemical availability of arsenic and antimony in industrial soils. Environmental Chemistry Letters, Vol. 3, 149-153. < Go to ISI >://000239114500002 Giacomino, A, ABOLlino, O, MALANDRINO, M, AND MENTASTI, E. 2011. The role of chemometrics in single and sequential extraction assays: A Review. Part II. Cluster analysis, multiple linear regression, mixture resolution, experimental design and other techniques. Analytica Chimica Acta, Vol. 688, 122139. 10.1016/j.aca.2010.12.028

GIBSON, M J, AND FARMER, J G. 1983 A survey of trace metal contamination in Glasgow urban soils Heavy Metals in the Environment, Vol. 2, 1141-1144.,

GIBSON, M J, AND FARMER, J G. 1986. Multi-step sequential chemical extraction of heavy metals from urban soils. Environmental Pollution Series B, Chemical and Physical, Vol. 11, 117-135. http://dx.doi.org/10.1016/0143-148X(86)90039-X 
Johnson, C C, Demetriades, A, Locutura, J, AND OtTesen, R T. 2011. Mapping the Chemical Environment of Urban Areas. (Wiley.) ISBN 978-0-470-74724-7

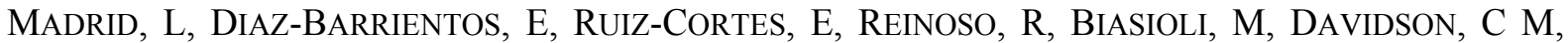
Duarte, a C, Grcman, H, Hossack, I, Hursthouse, a S, Kralu, T, LJung, K, Otabbong, E, Rodrigues, S, URQUHART, G J, AND AJMONE-MARSAN, F. 2006. Variability in concentrations of potentially toxic elements in urban parks from six European cities. Journal of Environmental Monitoring, Vol. 8, 1158-1165. 10.1039/B607980F

Nathanail, P, McCaffrey, C, Earl, N, Foster, N D, Gillett, A G, AND Ogden, R. 2005. A deterministic method for deriving site-specific human health assessment criteria for contaminants in soil. Human and Ecological Risk Assessment, Vol. 11, 389-410. <Go to ISI >://000228921900008

NATIONAL ReCordS SCOTLAND. 2016. Glasgow City Council Area - Demographic Factsheet. https://www.nrscotland.gov.uk/files/statistics/council-area-data-sheets/glasgow-city-factsheet.pdf

OKORIE, A, ENTWISTLE, J, AND DEAN, J R. 2011. The application of in vitro gastrointestinal extraction to assess oral bioaccessibility of potentially toxic elements from an urban recreational site. Applied Geochemistry, Vol. 26, 789-796. http://dx.doi.org/10.1016/j.apgeochem.2011.01.036

Palumbo-Roe, B, CAVe, M R, KlincK, B A, WragG, J, TAYlor, H, O'DOnNell, K, AND ShaW, R A. 2005. Bioaccessibility of arsenic in soils developed over Jurassic ironstones in eastern England. Environmental Geochemistry and Health, Vol. 27, 121-130. 10.1007/s10653-005-0128-1

Paterson, E. 2011. Geochemical Atlas For Scottish TOPSOIls. (MaCAuley Land Use RESEARCH INSTITUTE). ISBN:978-0-902701-00-7

Pelfrene, A, Waterlot, C, Mazzuca, M, Nisse, C, Bidar, G, AND Francis, D. 2011. Assessing $\mathrm{Cd}, \mathrm{Pb}, \mathrm{Zn}$ human bioaccessibility in smeltercontaminated agricultural topsoils (northern France). Environmental Geochemistry and Health, Vol. 33, 477-493.

R CORE TEAM. 2016. A Language and Environment for Statistical Computing. Vienna, Austria, R Foundation for Statistical Computing, https://www.R-project.org/.

Reis, A P, Patinha, C, WragG, J, Dias, a C, Cave, M, Sousa, A J, Batista, M J, Prazeres, C, Costa, C, Ferreira DA Silva, E, AND Rocha, F. 2014. Urban geochemistry of lead in gardens, playgrounds and schoolyards of Lisbon, Portugal: Assessing exposure and risk to human health. Applied Geochemistry, Vol. 44, 45-53. 10.1016/j.apgeochem.2013.09.022

Roussel, H, Waterlot, C, Pelfrene, A, Pruvot, C, Mazzuca, M, and Douay, F. 2010. Cd, Pb and $\mathrm{Zn}$ oral bioaccessibility of urban soils contaminated in the past by atmospheric emissions from two lead and zinc smelters. Arch Environ Contam Toxicol, Vol. 58, 945-954. < Go to ISI $>$ ://MEDLINE:20016887

SHARMA, K, BASTA, N T, AND GREWAL, P S. 2015. Soil heavy metal contamination in residential neighborhoods in post-industrial cities and its potential human exposure risk. Urban Ecosystems, Vol. 18, 115-132. 10.1007/s11252-014-0395-7

SiAlelLi, J, URQUHART, G J, DAVIDSON, C M, AND HuRSTHOUSE, A S. 2010. Use of a physiologically based extraction test to estimate the human bioaccessibility of potentially toxic elements in urban soils from the city of Glasgow, UK. Environmental Geochemistry and Health, Vol. 32, 517-527. 10.1007/s10653-010-9314-x

StOCKBURGER, D. W. 2001. INTRODUCTORY STATISTICS: CONCEPTS, MODELS AND APPLICATIONS. Missouri STATE UNIVERSITY OHIO: ATOMIC DOG PUBLISHING

USEPA. 1995. Method 3052: Microwave assisted acid digestion of siliceous and organically based matrices. Test Methods for Evaluating Solid Waste, United States Environmental Protection Agency.

WRAGG, J, AND CAVE, M. 2012. Assessment of a geochemical extraction procedure to determine the solid phase fractionation and bioaccessibility of potentially harmful elements in soils: A case study using the NIST 2710 reference soil. Analytica Chimica Acta, Vol. 722, 43-54. 10.1016/j.aca.2012.02.008

Wragg, J, CAVE, M, AND Gregory, S. 2014a. The Solid Phase Distribution and Bioaccessibility of Arsenic, Chromium, and Nickel in Natural Ironstone Soils in the UK. Applied and Environmental Soil Science, Vol. 2014, 12. 10.1155/2014/924891

WragG, J, CAVE, M, AND GREgORY, S. 2014b. The solid phase distribution and bioaccessibility of arsenic, chromium, and nickel in natural ironstone soils in the UK. Applied and Environmental Soil Science, Vol. 2014. WraGG, J, AND CAVE, M R. 2012. Assessment of a geochemical extraction procedure to determine the solid phase fractionation and bioaccessibility of potentially harmful elements 
in soils: A case study using the NIST 2710 reference soil. Analytica Chimica Acta, Vol. 722, 43-54. 10.1016/j.aca.2012.02.008

Wragg, J, Cave, M R, Basta, N, Brandon, E, Casteel, S, Denys, S e B, Gron, C, Oomen, A, REIMER, K, TACK, K, AND VAN DE WIELE, T. 2011. An Inter-laboratory Trial of the Unified BARGE Bioaccessibility Method for Arsenic, Cadmium and Lead in Soil. Science of the Total Environment, Vol. 409, 4016-4030.

Wright, J P, DieTrich, K N, Ris MD, HORNUNG, R W, WeSSEL, S D, LANPHEAR, B P, Ho, M, AND RAE, M N. 2008. Association of Prenatal and Childhood Blood Lead Concentrations with Criminal Arrests in Early Adulthood. PLoS Med Vol. 5. doi:10.1371/journal.pmed.0050101

Figure Captions

Figure 1. Map of soil sampling locations in the Glasgow area. Samples 19I, 20S and 24S (highlighted in bold) are known to contain COPR.

Map generated in ArcGIS (ESRI $\left.{ }^{\circledR}\right)$ geographic information system software

Figure 2. Plot of total $\mathrm{As}, \mathrm{Cr}$ and $\mathrm{Pb}$ concentrations in Glasgow soils stratified by land use type $\mathrm{G}=$ Domestic Garden $(\mathrm{n}=4) \quad \mathrm{I}=\operatorname{Industry}(\mathrm{n}=2) \quad \mathrm{P}=\operatorname{Park}(\mathrm{n}=8) \quad \mathrm{R} \quad=\quad$ Residential Grass Area $\quad \mathrm{S}=$ Sports Ground $(\mathrm{n}=5) \quad \mathrm{SC}=\operatorname{School}(\mathrm{n}=1)$

Figure 3. Plot of detectable bioaccessible $\mathrm{As}, \mathrm{Cr}$ and $\mathrm{Pb}$ concentrations in the Glasgow soil samples stratified by land use.

$\mathrm{G}=$ Domestic Garden $\quad \mathrm{I}=$ Industry $\quad \mathrm{P}=$ Park $\quad \mathrm{R}=$ Residential Grass Area $\quad \mathrm{S}=$ Sports Ground $\quad \mathrm{SC}=$ School

Figure 4. Plot of percentage bioavailable fraction of $\mathrm{As}, \mathrm{Cr}$ and $\mathrm{Pb}$ in the Glasgow soil samples stratified by land use.

$\mathrm{G}=$ Domestic Garden $\quad \mathrm{I}=$ Industry $\quad \mathrm{P}=$ Park $\quad \mathrm{R}=$ Residential Grass Area $\quad \mathrm{S}=$ Sports Ground $\quad \mathrm{SC}=$ School

See Table 1 for locations of Samples 20 and 24

Figure 5 Overview of data manipulation process to rationalise the geochemical information from the CISED extraction

Figure 6 Colourmap and associated dendogram for the combined CISED data matrix data. The dendrogram along the left-hand side shows how individual geochemical phases of the three groups link together. The horizontal lines divide the colourmap into clusters (indicated by C1-C16) and the vertical line separates the element composition data on the left-hand side from the extraction number data on the right. A high proportion of each component and an indication of its composition are shown by a yellow/orange/red colouration while a low proportion is indicated by a dark red or black colouration. 
$\mathrm{As}, \mathrm{Cr}, \mathrm{Pb}$ apportionment Glasgow soils

Figure 7 The abundance $\left(\mathrm{mg} \mathrm{kg}^{-1}\right)$ of the cluster types. The number of samples in each cluster are given on the boxes.

Figure 8 The abundance $\left(\mathrm{mg} \mathrm{kg}^{-1}\right)$ of the cluster types in the three soil sample groupings (if present). The number of samples in each cluster are given on the boxes.

Figure $9 \mathrm{As}, \mathrm{Cr}$ and $\mathrm{Pb}$ median cumulative extractability using the CISED and the UBM. The CISED data are shown by a solid black line and the median bioaccessibility is shown by a dashed black line. Rows $\mathrm{A}-\mathrm{C}$ show the individual $\mathrm{As}, \mathrm{Cr}$ and $\mathrm{Pb}$ extractability in the three soil sample groupings and columns 1 - 3 compare the extractability of $\mathrm{As}, \mathrm{Cr}$ and $\mathrm{Pb}$ within each group. 